\title{
Indigenous communities and their food systems: a contribution to the current debate
}

\author{
Diosey Ramon Lugo-Morin(D
}

\begin{abstract}
The present study contributes to the debate on the need to develop unconventional strategies for mitigating food insecurity in the world. Ancient peoples' knowledge and experience may help to deepen the debate and establish a line of work based on the case study herein presented. The study proposes the promotion of indigenous food systems through the institutional resilience approach. There is a need to attack a global problem that affects the entire planet, including countries that have agricultural systems sensitive to the problem of climate change. According to the United Nations Food and Agriculture Organization (FAO), the population suffering from hunger has been growing in the last 3 years, which is similar to the famine levels recorded in the previous decade. This would contribute to the development of new strategies of action that allow not only the strengthening of today's localized agrifood systems but also the revaluation of food systems forgotten or guarded by the indigenous populations that remain present.
\end{abstract}

Keywords: Totonacapan, Resilience, Indigenous, Institutions, Food, Tutunakú

\section{Introduction}

Food insecurity is a global problem affecting the entire planet, in particular, countries with agricultural systems sensitive to climate change (e.g., variability of rainfall, temperature, drought, floods).

Food insecurity is understood as a situation where people do not have continuous physical or economic access to nutritious and safe food, as the distance to food access grows to the extent that communities would be placed in food poverty.

The lack of food, particularly quality food, not only contributes to malnutrition of the population, but on a wider scale is also the main slowing element of rural territories, leading to hunger, poverty, and unemployment.

According to the available data, the number of people suffering from hunger has grown during the last 3 years, returning to the levels of a decade ago. It is currently estimated that the absolute number of people worldwide affected by food insecurity has increased from around

Correspondence: diosey.ramon@uiep.edu.mx

Research and Postgraduate Studies, Intercultural University of Puebla State, Calle Principal a Lipuntahuaca s/n. Lipuntahuaca, Huehuetla, C.P. 73475 Puebla, Mexico
804 million in 2016 to almost 821 million in 2017. The situation is worsening in South America and most regions in Africa and Asia [1].

At global level, governance concerned about the situation has begun to implement mechanisms to address the problem; one of the main actions is the 2030 Agenda for Sustainable Development, the efforts of foundations such as the Bill \& Melinda Gates Foundation through their Grand Challenges Explorations financing program, and other equally important efforts, such as that by FAO learning and promotion of indigenous food systems.

As a whole, these efforts are important, but insufficient. If we truly want to end hunger and ensure food access by 2030, it is necessary to rethink the strategies of action. The promotion of indigenous food systems is proposed, but with an institutional resilience approach, that is, to mitigate the problem from local informal institutions; this translates into learning local actions to have a global impact.

The present study was proposed to provide a response in this direction, and aims to assess the institutional resilience approach to strengthen indigenous food systems in rural territories. To fulfill the study objective, a theoretical 
investigation will be carried out in different temporalities that will lead to the modeling of an institutional resilience approach.

This study is part of a more extensive research carried out in the Sierra Norte de Puebla in the years 20172018, historical, cultural and social elements are added about the native peoples with emphasis on Mesoamerica. For greater compression, a case study of an indigenous group from the municipality of Huehuetla belonging to the Sierra Norte de Puebla region in Mexico is analyzed (Fig. 1).

The reason for this study is to give a possible response to a challenge, the global food security within the framework of the informal institutions that the indigenous groups have created throughout their existence. The indigenous have been able to protect the knowledge that has allowed the perpetuity of their agrifood systems over time, this knowledge can be used in those territories with food poverty.

\section{Ethnic food origin}

The food systems presented in general terms and those described in the case study are mostly Mesoamerican. The Mesoamerican agricultural systems have an age of more than $2500 \mathrm{BC}$, a period of time called preclassic. Indigenous communities have had extensive knowledge about crop cycles for millennia to the present and have had the ability to build and rebuild their worldview around their own cultural dynamics [2, 3] (Fig. 2).

\section{Indigenous food systems}

Since its appearance on Earth, Homo sapiens has obtained food from the biosphere, first at the individual level with hunting and gathering [4]. Subsequently, at group level, $H$. sapiens has obtained food using reproductive strategies adapted to its environment [5]. Homo sapiens groups became numerous, and it was necessary to refine their ways of life; the mediating element for achieving a level of sophistication therein was culture.

In this manner, different social groups around the world adapted and in turn configured their territory to survive. Based on this logic, each territory had a specificity that corresponded to the social group with which it was linked.

The previous approach assumes that each social group and its territory have configured their own food systems, that these systems have been refined since ancient times, and that many of them are valid because the man-nature relationship has been harmonious and mediated effectively by the element of culture, which exhibits different informal expressions for its continuity over time.

Understanding these processes in a timeline where we distinguish the past, present, and future of food production can contribute to the proposal of new action strategies that enable not only strengthening of the contemporary localized agrifood systems but also the revaluing of food systems forgotten or guarded by the original populations (Fig. 3).

\section{Past}

The Mesoamerican agricultural systems have maintained a basic continuity from remote times to the present. According to the hard-core theory of knowledge, the plant cycle has been unchanged for millennia until today; this persistence is due to the temporal trajectory of the worldview of some indigenous groups [3].

The formation of the hard core is due to the refinement of the social, concrete, daily, and practical experiences produced over centuries. The organization of components in the system, the adjustment and inclusion of innovations, and the recomposition after the dissolution or loss of elements all depend on the hard core. At least a part of this hard nucleus has, since the time of the first Mesoamerican sedentary agriculture, resisted conquest and evangelization by long colonial life, and is present in today's indigenous peoples as one of the components integral to tradition [6].

In this case, we may refer to indigenous peoples as the original inhabitants with extensive knowledge of the management of production and their agricultural practices; this knowledge and perception of nature has allowed them to build the values, beliefs, and traditions that many indigenous groups practice today. This need for a belief, value, and tradition system is a means of apprehending their environment rationally and emotionally [3]. Examples of these indigenous groups are documented in the work of [2].

The origin of Mesoamerica can be traced to the Preclassic period (2500 years ago), when nomadic peoples who practiced agriculture came to depend in such a way on the products of their crops that they settled definitively beside them [3].

From Preclassic times, the ancient inhabitants of Mesoamerica knew the attributes of nature and combined that knowledge with cultural elements (parties, rituals, dances) to establish and maintain their food systems.

The environmental diversity in the development of contact between the first sedentary people was vital. The intense exchange of products peculiar in the different media was the catalyst for many other forms of interrelation, which propitiated since ancient times the joint construction of a common history and cultural tradition. Men forged a vision of the world from similar needs solved with similar resources [3].

Plant domestication specialists have recognized that Mesoamerica is one of the oldest and most dynamic areas in plant management and domestication and in the diversification of agricultural systems of the American continent [7-9]. 


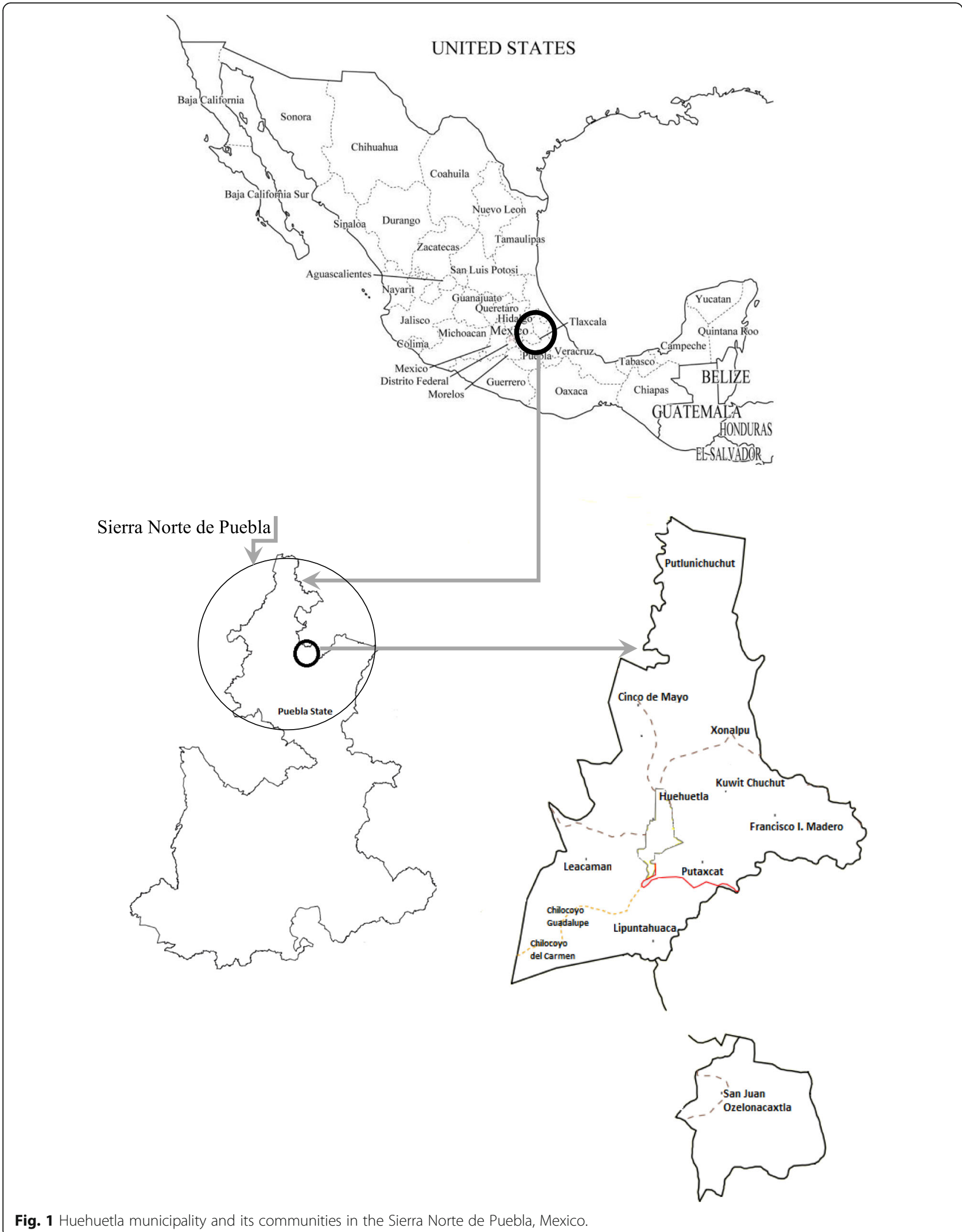

Fig. 1 Huehuetla municipality and its communities in the Sierra Norte de Puebla, Mexico. 


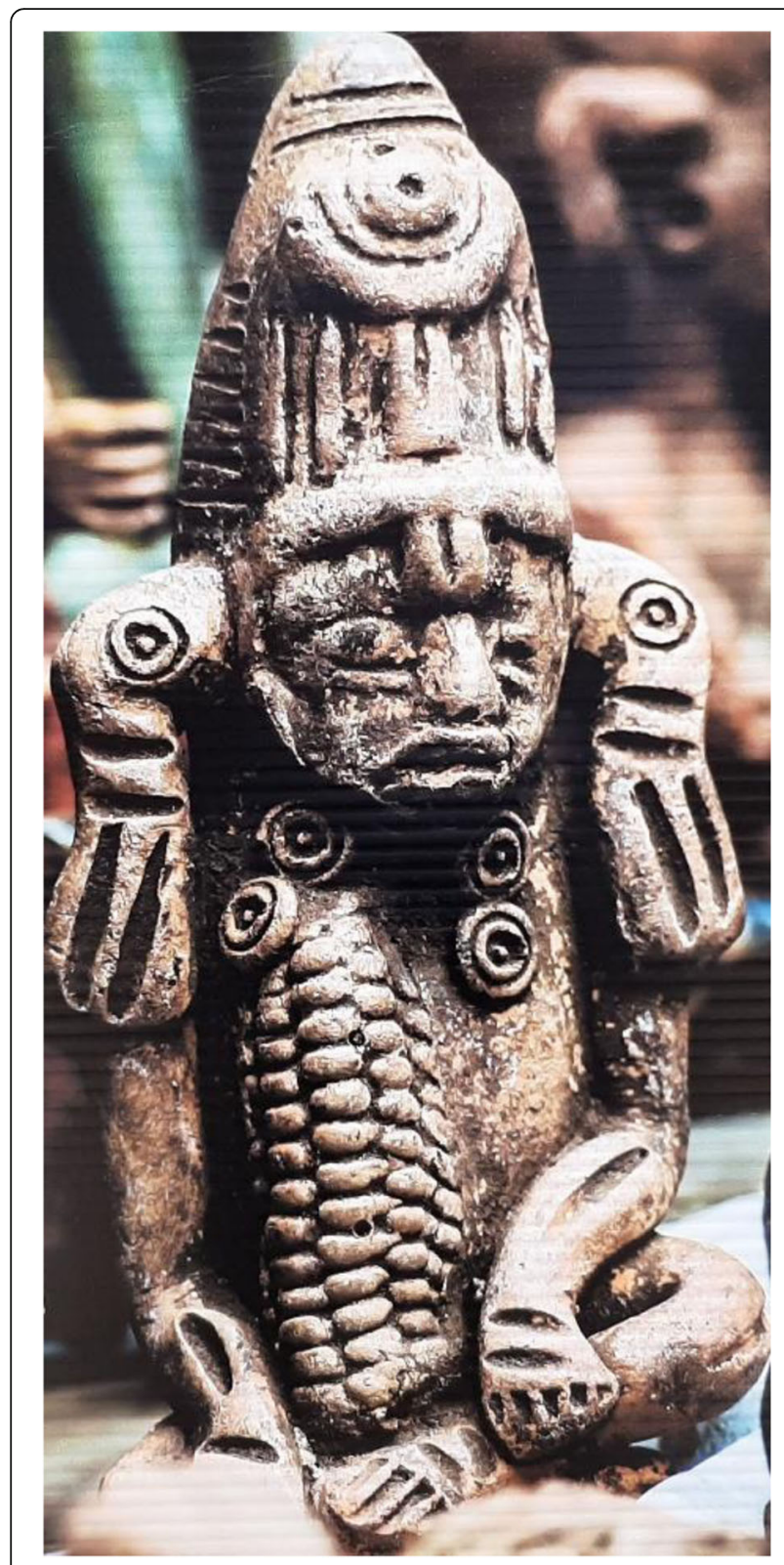

Fig. 2 Deity the Maize. Originally from the Quiché region in the indigenous market of Chichicastenango, Guatemala. Quiché in Wikipedia.org, 2018

The foregoing implies recurrent cultural processes in historical terms of the construction of informed institutions that have shaped plant management and domestication. Under this logic, institutional resilience has been key in indigenous food systems; institutions have preserved unchanged, until today, the agricultural practices of indigenous groups.

The past events can be useful elements for constructing strategies for the future, that is, it is possible to form corrective public policies in the context of food security if we examine the experiences of the past [10].

\section{Current}

In the debate on the global economy and sustainable development, one of the issues of greatest concern has been and continues to be the overpopulation. Since the industrial revolution, the number of inhabitants on Earth has increased exponentially, from 1 billion around 1800 to 7.4 billion in 2016 [11].

The situation described poses a major threat to guaranteeing food security for the entire world population. According to the United Nations Food and Agriculture Organization [12], it would be necessary to increase food production worldwide by more than $50 \%$ to supply the more than 9 billion people projected to inhabit the planet by 2050 .

Currently, some proposals for overcoming food insecurity fall under capitalist-style conventionalism, as proposed by [11, 13], and indicate the need to increase planting areas, intensities, and yields.

Other proposals are more refined, i.e., the study of agroecological and food fields. From this perspective, it is possible to define in a heuristic, instrumental, and discursive manner the agrarian mesoregions in a country, continent, or the planet, and study their articulation of ecology, agriculture, and food. In the mesoregions, agricultural production areas are articulated with the territories of food consumption through the flow of merchandise, technologies, information, and people [14].

On the other hand, here we argue that the mesoregions would enable the mapping and full elucidation of the extension and adaptation of plants that changed human survival in different territories; the relationships of cooperation, coordination, and power established between producers, distributors, and consumers; and account for the importance of the ecological diversity of the agroecosystem for developing agriculture and feeding, and of the multiplicity of forms of adaptation coexisting therein.

Finally, efforts have been made the in constructing action strategies oriented towards indigenous food systems. These guidelines focus on the debate on food systems, agroecology, and nutrition, including traditional food producers and knowledge holders. The strategies involve collecting data on the knowledge of traditional foods; native plants use and management; preserving native seeds, forests and agrobiodiversity; and linking indigenous peoples to markets [15].

Based on the previous strategies, the intends to establish a permanent knowledge dialog with the indigenous peoples worldwide that enables visualization of the design of global public policies aimed at combating food poverty and their implementation. The FAO has identified seven sociocultural regions to represent the indigenous peoples of the world: Africa; Asia; Central America, South America, and the Caribbean; the Artic; Central and Eastern Europe, Russian Federation, Central Asia, and Transcaucasia; North America; and the Pacific [15]. 


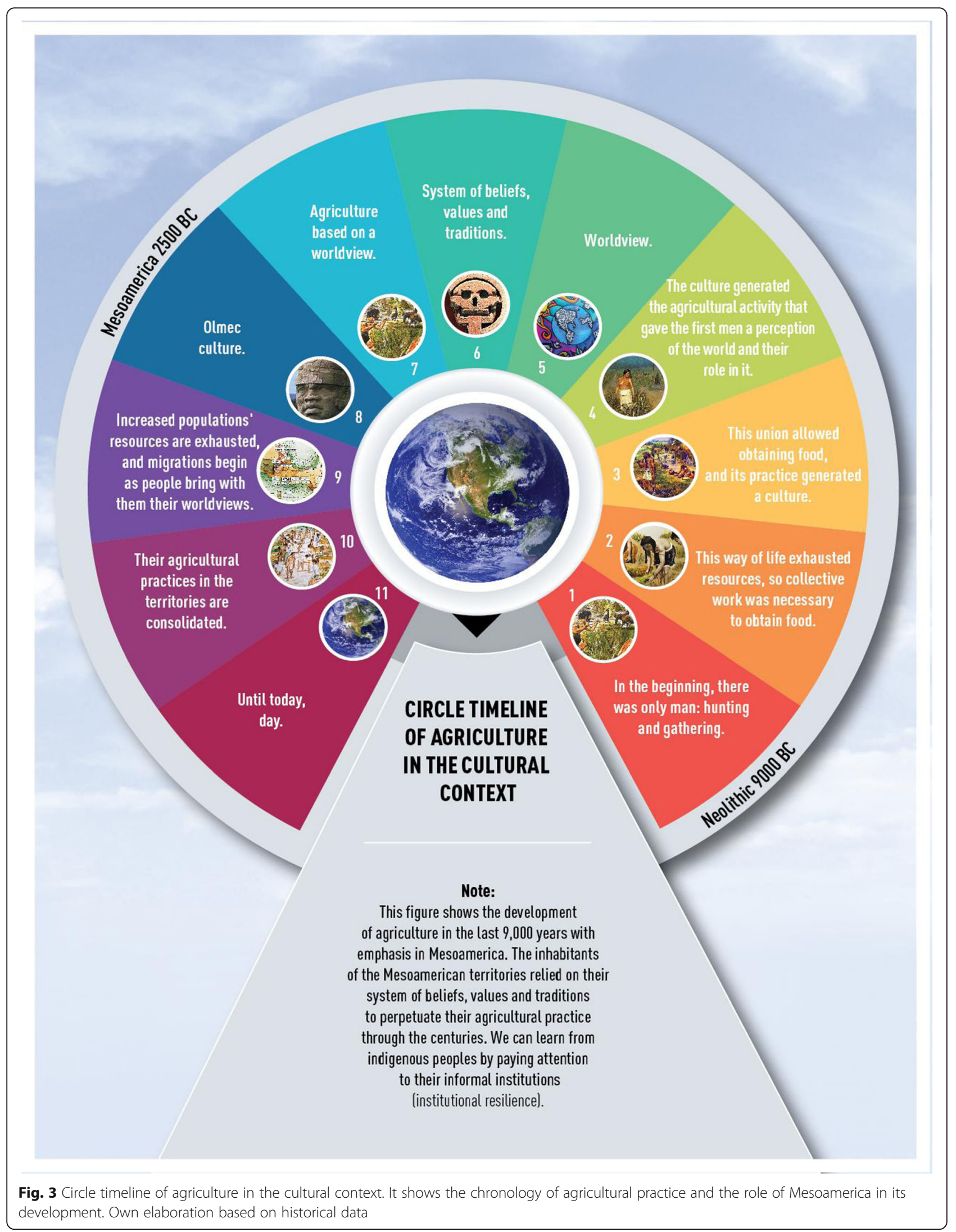




\section{Future}

The FAO shows a discouraging panorama; food insecurity is growing steadily, and strategies for mitigating it are insufficient, and the report shows the continued inability to reduce hunger in a world facing new challenges in the context of climate change, armed conflicts, falling raw material markets, population growth, environmental degradation, and unsustainable management of natural resources [1].

There is an urgent need to accelerate and expand the scale of actions that strengthen the resilience and adaptive capacity of people and their livelihoods to extreme climate variability and conditions. The above generates the question: Is it possible to reach, by 2030, objective 2 of the Agenda?

In response to the question, we can affirm that, currently, with the theoretical and conceptual tools available, it will be difficult to do so. We must be aware of this scenario and propose new tools that enable the development of means for ensuring food for the entire world population.

Some authors propose a genuine sustainability transition for achieving sustainable food and nutrition security in the face of climate change. Agrifood sustainability transitions refer to the transformation processes needed to move towards sustainable agrifood systems [16].

To advance this proposal is necessary to review and analyze the theoretical and conceptual tools used to understand and promote the transition towards sustainability. With the approach of these tools, the author expects a magic formula that integrates all those tools and fosters transitions towards sustainable agrifood systems [16].

Other approaches, see the need for a Great Food Transformation, defined as a substantial change in the structure and function of the global food system to work with different central processes and feedback. This transformation will not occur unless there is widespread multisectoral and multilevel action to change the food consumed, how it is produced, and its effects on the environment and health while providing healthy diets for the world population [17].

This logic establishes five easily implemented strategies and recommendations for achieving a sustainable transformation of the food system. Each strategy has a solid evidence base; modeling and analysis show the potential effectiveness of these strategies for achieving a sustainable transformation of the food system. The strategies are proposals for initiating processes, and are as follows: (i) seek international and national commitment to change towards healthy diets, (ii) reorient agricultural priorities of producing large quantities of food to producing healthy foods, (iii) sustainably intensify food production, generating high-quality production, (iv) sound and coordinated governance of land and oceans, and (v) at least halving food loss and waste, in line with the 2030 Agenda [17].

A review of the theoretical positions that emerge for mitigating food insecurity at global and local level show an important advance and concern about the subject, but they remain insufficient and do not contribute anything novel that allows a robust debate to ensure food at the global level. By this logic, it would be convenient to look to unconventional options, theoretical-conceptual tools that advance and strengthen a solid proposal, as in the case of the institutional resilience approach.

\section{Institutional resilience approach}

Institutional resilience is a concept that has been addressed for more than two decades. Recent studies apply the concept from the presence of institutions, also defined as group behavioral norms, which are capable of adapting to the political, social, economic, and ecological changes of the system $[18,19]$.

In the present study, the term "institutions" is deepened to give rise to the meaning "informal institution". Here, informal institutions become relevant because they allow the locating of institutional resilience, understanding this concept as the adaptive capacity of a system of beliefs, values, and traditions in a specific territory to generate changes driven by historically inherited cultural expressions, which in most cases creates environments that produce individual and collective well-being.

Informal institutions have been the subject of intense debate in Latin America and in much of the rest of the world. Before delving deeper into the subject, it would be convenient to specify the concept of "institution".

The institutions are a set of formal and informal limitations created by human beings or spontaneously arising from their relationships, and mechanisms to enforce their agreements. Formal limitations are written rules, such as constitutions, laws, and contracts, whose modification implies different degrees of difficulty. These rules regulate exchanges and create incentives for individual action. Informal limitations are culturally inherited customs, traditions, conventions, and codes of conduct [20].

The present analysis establishes the distinction between formal and informal institutions, the latter being a system of rules that regulate individual behavior and their interactions in a defined space. To know the role and configuration of informal institutions, it would be expedient to deepen their genesis.

The best way to understand informal institutions is to visualize them as systems of symbolic relationships; the world of everyday life is the world of institutions in their informal aspect. Informal institutions are defined by their functional and dysfunctional components, the source from 
which they arise, the fields in which they are expressed, and properties that make them observable $[21,22]$.

When informal institutions are present, the belief, value, and tradition systems that affect the environment (positively or negatively) are created progressively; the promoted changes originate chain reactions, that is, disturbances or crises that promote within the system readjustments oriented to recovery or transformation.

This logic has allowed many indigenous peoples to perpetuate their survival strategies, allowing indigenous populations to conserve their ancestral food systems; these systems have remained and have survived presentday modernity because the communities of indigenous people have been able to incorporate external cultural elements.

In Mesoamerica, several examples of indigenous communities are mentioned that have preserved agricultural practices and crops for millennia to the present $[2,3]$.

This approach proposes the identification of those indigenous food systems in the regions where indigenous communities live and to resume ancestral agricultural practices and crops, reintroduce them to their territories, and approach new territories where there are food deficiencies.

\section{Experiences in a framework of institutional resilience}

To obtain an idea of the application of the institutional resilience approach, we describe the concrete experience of the Totonac indigenous group in the municipality of Huehuetla, Puebla, Mexico.

Huehuetla was founded in 1550 and has a total population of 15,689 , with an indigenous language speaker population that exceeds $89 \%$ with reference to the total. Huehuetla has a very high degree of marginalization and a high degree of lag. Up to $46 \%$ of the population live in extreme poverty [23].
In Huehuetla, a mountain-type relief predominates, the climate (according to Köepen) is (A) C (fm): humid semester of group $\mathrm{C}$, and the average annual temperature exceeds $18{ }^{\circ} \mathrm{C}$. In the colder months, the temperature is lower than $18{ }^{\circ} \mathrm{C}$; in the hotter months, the temperature exceeds $22^{\circ} \mathrm{C}$. The municipality is divided into 12 communities that form the territory of Huehuetla, sharing a belief, value, and tradition system that has allowed a continuum of their reproductive strategies for several centuries.

The access to different ecological floors has allowed the Totonac to survive certain climatic contingencies and was the cause of the first conquest (Fig. 4). The Valley of Mexico was, as evidenced by the great famine of the early sixteenth century before the arrival of Hernán Cortés, sensitive to climate change, and control of the Totonacapan (the Sierra Norte de Puebla) ensured a permanent source of food supply to the Empire [24].

The double conquest of the Totonac indigenous group; first by the Mexica Empire and then by the Spaniards, contributed to the construction of their worldview; simultaneously, their management of the agroecosystems in the different ecological levels allowed the development of a reproductive strategy that until today remains in force.

The previous approach shows the relevance of the magic-religious world of the Totonac, as well as their values, knowledge, and traditions. The religious identity reconfiguration is associated with the manner in which a social group perceives and constructs reality, as the religious experience is integrated into the symbolic universe of the community, providing its members with security and a sense of belonging and contributing elements of special significance in the local food system [25].

The Totonac agrifood system is a space between 1000 $\mathrm{m}^{2}$ and $5000 \mathrm{~m}^{2}$ where wild and introduced species are established (Figs. 5 and 6). This system has been adjusted to the different altitudes of the Totonac territory. Numerous wild species are integrated into the food system for

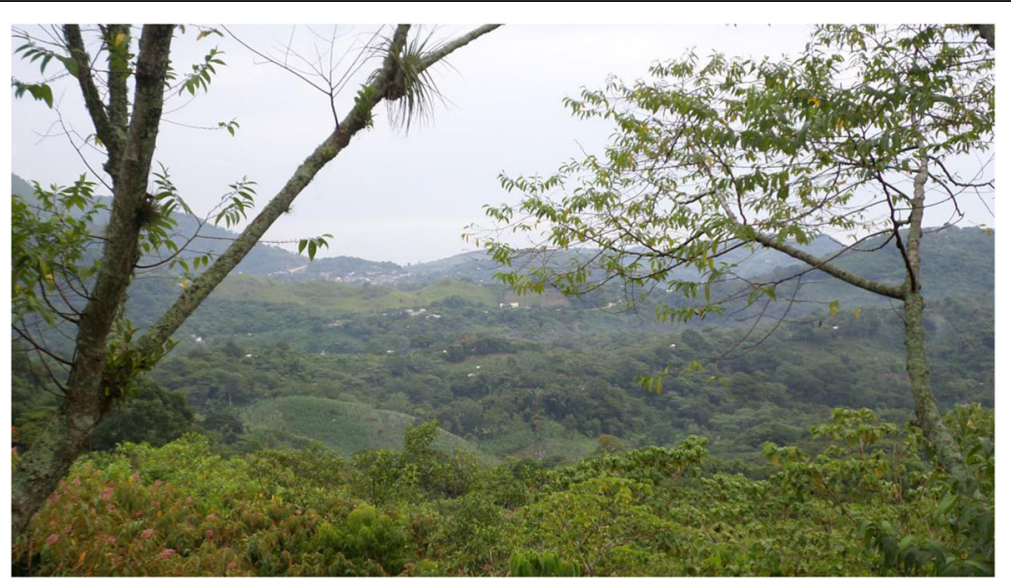

Fig. 4 Sample of the representative landscapes of the Sierra Norte de Puebla, Mexico. The landscape shows the different ecological floors 


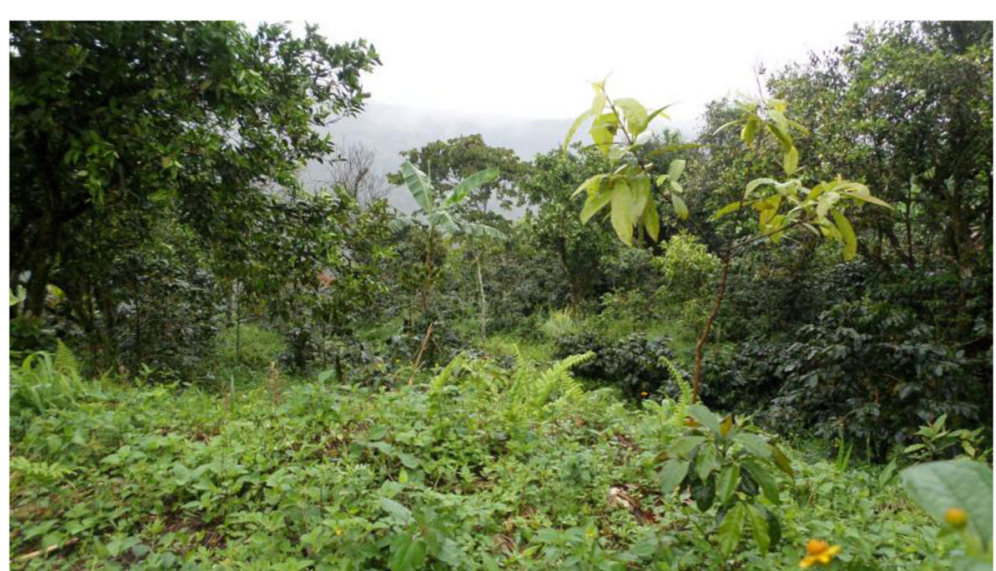

Fig. 5 Sample of a totonac agrifood system in San Juan Ozelonacaxtla, Huehuetla. The different species in the totonac agrifood system allow a livelihood throughout the year.

their medicinal, biomass, or edible properties (quelites), both in the upper layer of vegetation and in the lower floor. These practices have led to a process of domestication of wild plants managed and protected within the food system. The most common species are chalahuites (Inga spp.), orange (Citrus sinensis), Maize (Zea mays), plátano (Musa spp.), mamey (Pouteria sapota), alache (Anoda cristata), chaya (Cnidoscolus chayamansa), quelite cenizo (Chenopodium album), purslane (Portulaca oleracea), papaloquelite (Porophyllum macrocephalum), and coffee (Coffea arabica).

According to the Totonac worldview, the territory is not only a provider of natural resources, it is also inhabited by beings with whom humans have mutually supportive relationships, called owners or lords. These are deities the Totonacs consider non-humans in charge of protecting different areas of the territory. The owners of the mountain, the water, the stones, the earth, and the fire are recognized.
The Totonac food system reveals a strategy of socioeconomic reproduction that integrates a belief, value, and tradition system that has been configured historically in the territory and that incorporates new elements that have influenced the Totonacs' belief, value, and tradition system, not to make them disappear but to adapt to the changes. The specificities of this system demonstrate a logic of sustainability and institutional resilience that allows the activation of the territory in a constantly changing world, in which food goods will increasingly be needed.

This can be a response to climate change in the contexts of desertification, variability of precipitation, and agroenvironmental degradation [26]. The potential of indigenous food systems today is possible; bringing food to marginalized territories in the African, Asian, and Latin American continents can be a reality, where advances in science allow improvement in the transformation of food (e.g., flavor, food

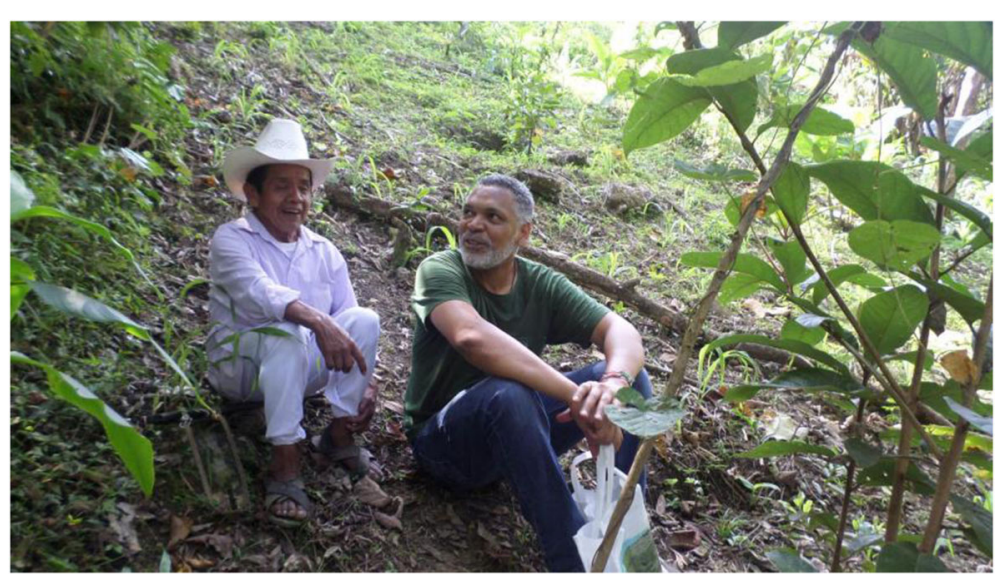

Fig. 6 Sample of a totonac agrifood system in Xonalpu, Huehuetla. The totonac indigenous have extensive knowledge about the management of ecological floors in the Sierra Norte de Puebla 
printing), improving not only the supply but also diet quality.

\section{Discussion of results}

Review of the literature on agrifood systems has emphasized the transition and transformation of food; the perspectives of $[16,17]$ agree on the implementation of multisector and multilevel changes to build a transition towards sustainability. These theoretical statements do not say anything new and only sustain the need to make changes to the food consumed, how it is produced, and the effects on the environment and health.

The analysis of the temporality of food systems allows the recognition of a richness in the manner its different expressions are approached in a historical context; since mankind has been able to capitalize on the natural resources of a territory, it has seen the need to create a perceptive means of interacting with its environment as best as possible.

Culture has been a fundamental element in the construction of strategies for interacting with the territory and its natural resources, and has been so important that it has allowed the maintenance and evolution of rudimentary food systems historically up to the present.

The arguments of $[2,6]$ on the historical persistence of agricultural practices and crops are true and constitute the basis for the construction of new, unconventional strategies for understanding and implementing a theoretical model that carries food systems forgotten or guarded by indigenous populations to territories with food poverty.

This model should be based on the FAO methodology that has determined seven indigenous sociocultural regions globally, i.e., Africa; Asia; Central America, South America, and the Caribbean; the Artic; Central and Eastern Europe, Russian Federation, Central Asia, and Transcaucasia; North America; and the Pacific.

The next step is to identify and systematize in a historical context the food systems of these seven regions. The FAO has up to this point made an important advance in wild foods [27]. The identification and systematization of this knowledge is vital because it allows us to move towards the informal institutions that have allowed food systems to persist over time.

The institutional resilience approach is put in place because it recognizes the informal institutions that are part of the food systems, and the elements that shape the institutional resilience are identified and then progress to a replication phase.

\section{Conclusion}

The valuation and rescue of food systems guarded by indigenous communities can constitute a strategy for designing and implementing public policies aimed at mitigating food insecurity worldwide. New food processing technologies can help to broaden the impact of new foods on the supply and its quality.

The institutional resilience approach can be applied universally to mitigate food insecurity and generate new processes of local adaptation for many territories vulnerable to climate change.

It is important to recognize that native or indigenous populations have ancestral knowledge of food systems they have maintained for millennia; the use and exploitation of these systems is the key to deciphering a new theoretical model oriented towards sustainability and food provision to the territories that need it.

\section{Acknowledgements \\ The author is grateful for the support of the Intercultural University of Puebla State, Huehuetla, Mexico. The author also thanks the Totonac indigenous communities of Huehuetla who agreed to share information about their food systems.}

Author's contributions

DRLM designed the research, interpreted the data, and wrote the manuscript. The author read and approved the final manuscript.

\section{Author's information}

Diosey Ramon Lugo-Morin holds a PhD in Strategies for Regional Agricultural Development (Postgraduate College, Mexico). He is a professor of sustainable development of the Intercultural University of Puebla State, Mexico. He has published on various subjects, especially on sustainable development, ethnocompetitiveness, resilience, and climate change adaptation. He is currently interested in the institutional resilience challenges of indigenous territories

\section{Funding}

This study is funded by the Intercultural University of Puebla State, PFCE 2019.

Availability of data and materials

All data and materials have been presented in the paper.

Competing interests

The author declares that he has no competing interests.

Received: 17 September 2019 Accepted: 29 December 2019

Published online: 14 January 2020

References

1. FAO, FIDA, UNICEF, PMA, and OMS. El estado de la seguridad alimentaria y la nutrición en el mundo. Fomentando la resiliencia climática en Aras de la seguridad alimentaria y la nutrición. Rome: Food and Agriculture Organization of the United Nations; 2018.

2. Broda J. Ciclos agrícolas en la cosmovisión prehispánica: el ritual mexica. In: Broda JY, Good C, et al., editors. Historia y Vida ceremonial en las comunidades mesoamericanas: Ios ritos agrícolas. México: CONACULTAInstituto Nacional de Antropología e Historia/Universidad Nacional Autonoma de México/Instituto de Investigaciones Históricas; 2004. p. 35-60.

3. López A. El núcleo duro, la cosmovisión y la tradición mesoamericana. In: Broda JY, Báez-Jorge F, et al., editors. Cosmovisión, ritual e identidad de los pueblos indígenas de México. México: Consejo Nacional para la Cultura y las Artes-Fondo de Cultura Económica; 2001. p. 47-65.

4. Zihlman A. Women as shapers of the human adaptation. In: Dahlberg F, editor. Woman the gatherer. New Haven: Yale University Press; 1981. p. $75-120$.

5. Gough K. The origin of the family. J Marriage Fam. 1971;33(4):760-71.

6. López A. Cosmovisión y pensamiento indígena. México: Universidad Nacional Autonoma de México; 2012

7. Harlan J. Crops and man. Madison: American Society of Agronomy and Crop Science Society of America; 1975. 
8. Hawkes JG. The diversity of crop plants. Cambridge: Harvard University Press; 1983.

9. Smith BD. Eastern North America as an independent center of plant domestication. Proc Natl Acad Sci U S A. 2006;103(33):12223-8.

10. Brooks K, Place F. Global food systems: can foresight learn from hindsight? Glob Food Sec. 2019;20:66-71.

11. Luque K. Seguridad alimentaria y alimentos transgénicos. Observatorio Medioambiental. 2017;20:59-75.

12. FAO. The future of food and agriculture-alternative pathways to 2050 . Rome: Food and Agriculture Organization of the United Nations; 2018.

13. Jayne TS, Snapp S, Place F, Sitko N. Sustainable agricultural intensification in an era of rural transformation in Africa. Glob Food Sec. 2019;20:105-13.

14. González H. La exportación de frutas y hortalizas de México a América del Norte: 1980-2015. Jalisco: Universidad de Guadalajara; 2017.

15. FAO. Sistemas alimentarios indígenas, agroecología y las Directrices Voluntarias sobre la Gobernanza Responsable de la Tenencia: una reunión entre los pueblos indígenas y la FAO. Rome: Food and Agriculture Organization of the United Nations; 2015.

16. El Bilali H. Transition heuristic frameworks in research on agrofood sustainability transitions. In: Environment, development and sustainability; 2018. https://doi.org/10.1007/s10668-018-0290-0.

17. Willett W, Rockström J, Loken B, Springmann M, Lang T, Vermeulen S, et al. Food in the Anthropocene: the EAT-lancet commission on healthy diets from sustainable food systems. Lancet. 2019. https://doi.org/10.1016/S01406736(18)31788-4

18. Ostrom E. Governing the commons: the evolution of institutions for collective action. Cambridge: Cambridge University Press; 1990.

19. Lugo-Morin DR, Garcia-Sanchez E, Cruz-Vazquez RI. Beliefs, values, and traditions: re-thinking sustainable development using the Hñähñu example. Dev Pract. 2019;29(1):95-102.

20. North D. Institutions, institutional change and economic performance. Cambridge: Cambridge University Press; 1990.

21. Navarrete C. Institucionalismo informal: tras las huellas de un discurso institucionalista informal. Perfiles Latinoamericanos. 2016;24(47):283-306.

22. Schutz A. El mundo de la Vida cotidiana y la actitud natural. Las estructuras del mundo de la Vida. Buenos Aires: Amorrortu Editores; 1973. p. 25-40.

23. SEDESOL (Secretaría de Desarrollo Social). Catálogo de Localidades. Unidad de Microrregiones, CIBCEC-2006; 2007. www.microrregiones.gob.mx. Accessed 6 July 2017

24. Masferrer E. Cambio y continuidades entre los totonacos de la sierra Norte de Puebla. Tesis de Maestría. Puebla: Universidad Iberoamericana; 2006.

25. Lara MC. El culto a la santa muerte: la comunicación, la cultura y las creencias religiosas Como procesos de configuración de la subjetividad y la identidad grupal. In: Delich F, et al., editors. Muerte del sujeto y emergencia subjetiva. Colección POSDOC. Córdoba: Ediciones Comunicarte; 2014. p. 123-40.

26. Cámara-Leret R, Fortuna M, Bascompte J. Indigenous knowledge networks in the face of global change. Proc Natl Acad Sci U S A. 2019;116(20):9913-8.

27. FAO. In: Bélanger J, Pilling D, editors. The state of the World's biodiversity for food and agriculture. Rome: FAO Commission on Genetic Resources for Food and Agriculture Assessments; 2019. http://www.fao.org/3/CA3129EN/ CA3129EN.pdf. Accessed 28 Feb 2019.

\section{Publisher's Note}

Springer Nature remains neutral with regard to jurisdictional claims in published maps and institutional affiliations.

Ready to submit your research? Choose BMC and benefit from:

- fast, convenient online submission

- thorough peer review by experienced researchers in your field

- rapid publication on acceptance

- support for research data, including large and complex data types

- gold Open Access which fosters wider collaboration and increased citations

- maximum visibility for your research: over $100 \mathrm{M}$ website views per year

At BMC, research is always in progress.

Learn more biomedcentral.com/submissions 